\title{
Museum \& Society special issue. Museum education today: creative synergies and pedagogic innovations in multicultural contexts
}

\section{Editorial note}

\author{
*Anastasia Filippoupoliti, **Stella Sylaiou
}

Museums as mere repositories for cultural artefacts have long disappeared giving their place to museums as active institutions that prioritize engagement with a diverse range of communities. In today's multicultural landscape ${ }^{1}$ that refers, reflects and at the same time adapts to diverse cultures, it is true that there is a growing international growing international recognition of the importance of ethnic diversity ${ }^{2}$ and a constant demand for museums to update their profile as social and learning settings (Ang 2005). Increasing emphasis has been put by museums, nowadays, on interacting with a variety of multicultural audiences, not only visitors and education programs' participants, but also educators and teachers, via a wealth of education programmes (Acuff and Evans 2014). Also, several examples of museum exhibitions, mostly temporary, set out to narrate and share the stories of various social and ethnic groups. Museum education offers theoretical insights and practical means to engage visitors, trigger aesthetic and cultural sensitivities, exercise creativity and imagination, increase tolerance, reduce prejudices (Sleeter and Grant 1988, after Chin 2013), display historical empathy (Skolnick et al. 2004), as well as respect for all, promote equity and justice, in order to address challenges of cultural dialogue, social inclusion, and new models of cultural identity (Innocenti 2014, p. 2). Museums need to adapt to a diversifying and multicultural society and shall offer accessibility to inclusive, comprehensive and creative educational experiences that embrace and foster cultural diversity, and provide to everyone the ability to live and participate equally in a pluralistic society.

This special issue has collected eight selected contributions that discuss the subject of museum education in today's multicultural contexts and transcultural dialogue and address some of the main questions that preoccupy researchers and museum practitioners:

- What are the new trends in multicultural museum education and how are they interact with 'individuals and groups from different cultural backgrounds?

- How museum educational programs can reach out and engage children and special groups of potential participants?

- How can the museum educators be supported?

- Can the museums become effective agents in social inclusion?

- How museums can approach their audiences via storytelling and narration?

- What can be museums' contribution to the development of the twenty-first century learner?

The focus of the articles lies on the strategies, cross-institutional synergies and pedagogic innovations pursued by a variety of museum and gallery types. International in its approach, this thematic volume has attempted to include as many perspectives as possible, offering to the reader critical discussion on a wealth of examples of museum education practice.

The first article Learning local immigration history in and out of the museum by Jeremy Stoddard, Alan Marcus, Kurt Squire and John Martin discusses three case studies of US museums, which serve as models for structuring historical inquiry in museum education programmes focused on local immigration history. The authors present both theoretical and practical models for museum and history educators to engage students actively in immigration history through the practices of the museum. They utilize models of practice from museum studies, history education, and new digital media focused on mobile technologies and Augmented Reality environments, in order to argue for a museum and public history approach to promote 
authentic historical inquiry into the traces of immigrant pasts in local communities and the ways, in which immigrant heritage is constructed.

The challenge of making connections between classroom and museum is discussed in the article Museums and early childhood education: providing opportunities for meaningful self-explorative experiences. Betsy Bowers, Dana Brightful, Carrie Heflin, Anna Hindley, Kimberlee L. Kiehl, Erin Pruckno, Cynthia Raso and Jaime Wolfe from the Smithsonian Early Enrichment Center in Washington, DC, discuss how museums and their resources can support early childhood educators and families in also engage actively and helping children to develop a positive racial self-identity. In their article they argue that museums can play a significant role in children's appreciation for others, respect and value for people with diverse cultural background.

The challenges and difficulties that museum educators face with the development of learning materials for school groups on the subject of financial education are analysed by Mieka Harris. In her paper Are coins small and boring? Developing an experiential based education programme, taking as a case study the recently-refurbished Citi Money Gallery of the British Museum, she considers the importance of developing close partnerships with school communities during the design phase of education programmes. Written from the perspective of a museum practitioner, the article, also, discusses the importance of involving teachers, as steering committees, at various stages of the programme, how local schools and communities should be engaged in evaluating pilot materials, as well as the opportunities that museum visits and museum objects offer to teachers' continuing professional development.

Two articles analyse multicultural museum education programs as tools for empowerment and social inclusion for involving disadvantaged and marginalized groups, such as Latino families and people with Alzheimer disease and related dementias.

Social inclusion of marginalized immigrants via museum education programmes is the issue analysed in the article Arte juntos/Art together: promoting school readiness among Latino children through parent engagement and social inclusion in a suburban museum by Zoila Tazi, Helena Vidal and Karen Stein. Arte Juntos/Art Together is a bilingual parent-child programme developed by a school-museum collaboration, which aimed at promoting school readiness and social inclusion for Latino families. The programme provided access to museums as enriching spaces for informal learning, personal empowerment and social inclusion. The authors propose a model of collaboration between museums and early childhood centers aiming at language improvement, gaining confidence, supporting self-expression, enhancing self-esteem and promoting social inclusion.

The article Report from the field: multi-cultural dialogue and transformative learning in Arts \& Minds Programs at the Studio Museum in Harlem by Carolyn Halpin-Healy poses the question of what we mean by 'learning' when we are working with people with Alzheimer disease and related dementias. Are museum education programmes for people with dementia encouraging transformative learning? The Arts \& Minds programme aims at the exchange of participants' and educators' ideas, stories and memories connected to art and the improvement of the well-being of people with dementia and their caregivers. The author argues that the powerful potential of multi-cultural dialogue in the museum space creates transformative learning experiences for participants and educators alike.

The next two papers discuss and demonstrate: (a) how museum objects can become storytellers and narrate stories about various cultures by making museum educational experiences meaningful and engaging, fostering democratic dialogue between communities with diverse cultural background, and (b) how museums explore the mutual understanding and cooperation with cultures whose heritage they exhibit.

In their paper, Houses of stories: the whale rider at the American Museum of Natural History, Billie Lythberg, Wayne Ngata and Jenny Newell focus on the dynamics that museum objects convey and the educational opportunities objects allow for attracting audiences of various age groups and ethnicities. In particular, authors analyse how Paikea, a carved wooden figure riding a whale, held at the Pacific Collection of the American Museum of Natural History became the central element and initiator of a series of cross-cultural encounter and appreciation. Authors argue how sharing narratives related to an object's cultural biography can enable an engagement that allows rewarding outcomes for its immediate participants and 
the audiences they reach out to. In that sense, museums can become 'zones of exchange' of emotions, imagination and creativity.

Tzu-I Chung in her article Multicultural museum education in and beyond exhibit: local and transnational synergies from Canada's oldest Chinatown explores the educational opportunities that have grown out of the temporary exhibition Tradition in Felicities: Celebrating 155 Years of Victoria's Chinatown, held by the Royal British Columbia Museum in Canada. The article, written from the point of view of a museum professional, discusses how one of the exhibited objects, a handcrafted lantern created in the 1930s by Victoria's Chinese Freemason, unfolded narratives about immigration and social justice. The hidden voices associated with the object's history inspired a cross-cultural aesthetic appreciation through its Chinese, transPacific, international and Canadian connections. The author argues that through community outreach and engagement, as well as local, national and transnational collaborations among educational and memory institutions, museums can promote intercultural understanding.

The final paper Museums, innovative pedagogies and the twenty-first century learner: a question of methodology by Maria Xanthoudaki examines and discusses the theoretical reflections of museums' contribution to the development of the twenty-first century learner. The article tackles the influences that the technological evolution has brought to our lives and the consequent requirements for 'new' learning and skills. It, then, examines how different elements of new pedagogies and approaches could reinforce the twenty-first century learner and the contribution that museums could make integrating their unique identity and approach with elements from the new pedagogies.

In this special issue we explore the potential of creative synergies and pedagogic innovations in multicultural contexts and the role of museums as social mediators, in order to successfully approach, involve and engage underrepresented social groups. We hope that readers will enjoy reading this selection of articles, as these do not only offer a reading challenge, but also a motivation for opening up new parameters in the burgeoning field of museum education.

\section{References}

Acuff B. J., Evans L. (Eds.) (2014). Multiculturalism in Art Museum Today, Lanham, MD: Rowman \& Littlefield.

Ang, I. (2005). The Predicament of Diversity: Multiculturalism in Practice at the Art Museum, Ethnicities, 5(3): 305-320.

Blum, L.A. (1992). Antiracism, Multiculturalism, and Interracial Community: Three Educational Values for a Multicultural Society, Office of Graduate Studies and Research, University of Massachusetts, Boston.

Chin, C. (2013). Key dimensions of a multicultural art education curriculum. International Journal of Education \& the Arts, 14(14). Retrieved [Friday, February 20, 2015] from http://www.ijea.org/v14n14/

Multiculturalism, Stanford Encyclopedia of Philosophy, retrieved [Friday, February 20, 2015] from http://plato.stanford.edu/entries/multiculturalism/

Innocenti, P. (2014). Introduction: migrating heritage - experiences of cultural networks and cultural dialogue in Europe. In: Innocenti, P. (ed.) Migrating Heritage: Experiences of Cultural Networks and Cultural Dialogue in Europe. Ashgate: Farnham, pp. 1-24.

Skolnick, J., Dulberg, N., Maestre, T. (2004). Through other eyes: Developing empathy and multicultural perspectives in the social studies (2nd ed.). Toronto, Ontario: Pippin.

Sleeter, C. E., Grant, C. A. (1988). Making choices for multicultural art education: Five approaches to race, class, and gender. Columbus, $\mathrm{OH}$ : Merill. 


\title{
Notes
}

1 By the term multiculturalism we mean the interaction and communication between diverse cultures in the framework of a pluralistic and democratic society that provides tolerance, respect, equal opportunities for all, inclusion and community empowerment and it refers to "cultural life, cultural expression, achievements, and the like" (Blum 1992, p. 14 after Multiculturalism, Stanford Encyclopedia of Philosophy) .

2 Inglis Chr., Multiculturalism: New Policy Responses to Diversity, Management of Social Transformations (MOST) - UNESCO, Policy Paper - No. 4 (1995), http://www.unesco.org/most/pp4.htm

\section{Acknowledgements}

We cordially thank all those authors who submitted articles for review; even though some of these articles did not fit the particular aims set by the journal, they overall presented excellent proposals for the field of museum education, and the anonymous reviewers for their valuable comments and suggestions on the submitted articles. We owe our deepest thanks to Dr Kate Hill, the editorial committee of the journal and Jim Roberts for their support during the editorial process.

*Anastasia Filippoupoliti is assistant professor in museum education at the Democritus University of Thrace in Greece. Her research interests are interdisciplinary and span the fields of museology, museum education and science communication. Among her publications is the two-volume edited book Science Exhibitions: Communication and Evaluation and Science Exhibitions: Curation and Design (Edinburgh: MuseumsEtc, 2010).

\author{
Anastasia Filippoupoliti \\ Assistant Professor, Ph.D. \\ Department of Education Sciences in Early Childhood \\ Democritus University of Thrace \\ Alexandroupolis, Greece \\ e-mail: afilipp@yahoo.gr
}

** Stella Sylaiou is an adjunct faculty member of the MSc in Cultural Organizations Management at the Hellenic Open University in Greece. She has participated in nine research projects; she has nine publications in scientific journals and twenty-two peer-reviewed articles in conferences. Her research interests lie in the areas of museum education, cultural communication, cultural informatics and museology.

\section{Stella Sylaiou}

Adjunct Faculty Member, PhD

MSc in Cultural Organizations Management

Hellenic Open University

Parodos Aristotelous 18, 26 335, Patra, Greece

E-mail: stella.sylaiou@ac.eap.gr 